\title{
Hubert Humphrey on the Death of F.D.R.
}

JOH N N W M A N

April 12, 1970, marks the twenty-fifth anniversary of the death of President Franklin D. Roosevelt. To commemorate this anniversary, The University of Iowa Libraries are publishing here, for the first time, a letter from Hubert Humphrey to Henry A. Wallace written at the time of President Roosevelt's death. This letter, with a copy of Wallace's reply, was found in 1968 during the processing of the Henry A. Wallace Manuscript Collection in The University of Iowa Libraries. $^{1}$

President Roosevelt died in Warm Springs, Georgia, on April 12, 1945. ${ }^{2} \mathrm{He}$ had been vacationing and resting at the Warm Springs Foundation since the end of March on the advice of his physicians. The President had spent the morning of April 12 chatting with friends and relatives. At 1:15 p.m., while sitting for a portrait, he had collapsed in his chair and was taken to his bedroom. He was attended by his physician, Commander Howard G. Bruenn, and later by Dr. James E. Paullin. Despite their efforts, President Roosevelt died of a cerebral hemorrhage at 3:35 p.m. Mrs. Roosevelt, other members of the family, and certain government officials were informed privately before Stephen Early, the White House press officer, released the news simultaneously to the three major news services at 5:47 p.m.

While it was the announcement of the President's death which prompted Hubert Humphrey to write the fascinating postscript to his letter to Secretary Wallace, it will be helpful in understanding the letter as well as the postscript to place both the writer and the re-

1 This collection, which numbers some fifty-four thousand items, is currently being indexed in detail.

2 The most detailed account of President Roosevelt's death is Bernard Asbell, When F. D. R. Died (New York, 1961). The details here are taken from Asbell. 
cipient in historical perspective. At the time of President Roosevelts death, Henry A. Wallace was Secretary of Commerce. He had been Secretary of Agriculture from 1932 until 1940, and Vice-President of the United States from 1940 to 1944. He served as Secretary of Commerce from his confirmation on March 1, 1945, and was to continue in that position until September 20, 1946, when President Truman asked for, and received, his resignation. The history of the Democratic Party during this period and the differences between Wallace and Truman have been examined elsewhere at great length. ${ }^{3}$ For the purposes of this discussion, Wallace may be identified with the liberal or progressive branch of the party, while Truman may be said to have represented more conservative positions.

The liberal orientation of Secretary Wallace quite naturally attracted the favorable attention of Hubert Humphrey, who was then beginning his political career in Minneapolis, Minnesota. ${ }^{4}$ As his letter explains, he was engaged in his second campaign for mayor of Minneapolis. It was to gain support for this campaign and to ask consideration of a friend for an appointive job that Humphrey wrote to Secretary Wallace on April 10, 1945. The letter was typed in the offices of Humphrey's public relations firm, probably on April 12. When Humphrey signed the letter, he corrected the date, inking a " 2 " over the typewritten "0." The letter was still in Humphrey's office when he learned, almost certainly from a news broadcast, that President Roosevelt had died. After adjusting for time-zone differences, the time on Humphrey's postscript shows that he wrote to Secretary Wallace only nineteen minutes after the death announcement. The entire letter, with the postscript noted, follows:

Mr. Henry A. Wallace

April 12, 1945

Secretary of Commerce

Commerce Building

Washington, D.C.

Dear Mr. Wallace:

I have been intending to write to you for several weeks. First of all,

I want to extend my congratulations upon your appointment to

the position of Secretary of Commerce. I need not tell you how happy and

pleased all of us are out here in Minnesota because of your appointment

3 See, for example, Cabell Phillips, The Truman Presidency (New York, 1966), pp. 37-47. Also, John Gunther, Roosevelt in Retrospect (New York, 1950), pp. 347-350.

4 Biographical information about Humphrey in this account is taken from Winthrop Griffith, Humphrey-a Candid Biography (New York, 1965). 
to this important post in our government. Already favorable reports are coming to the attention of the public as to your activities in this office. The American people are going to have their opportunity to truly evaluate and understand your practical approach to the problems which confront our economy now and in the post war period. It makes all of us feel much more secure and much more hopeful as to the future when we know that you are in a position where you can establish policy and influence the general trend of the post war planning and readjustment. I need not tell you that your being Secretary of Commerce and coming directly in contact with the nations great industrial and business leaders will be of invaluable assistance to you in the determining of your political future. I want to keep reminding you that Minnesota is expecting you to be our Presidential candidate in 1948. As I have said to you on previous occasions, I will do everything within my power to help mobilize the progressive forces in this great midwest area behind you and your program.

I regret that I was not able to spend a little time with you while I was in Washington. I surely was surprised to see you in Mayor LaGuardia's office in New York but was somewhat disappointed when I went to the reception later in the evening only to find out that you had already left. I did, however, spend a good deal of time with Harold Young and saw our mutual friend, David Carr, so I felt somewhat posted on the events that were taking place preceding your confirmation to the Secretaryship. I also spent a good deal of time with Joe Cloud who, as you know, was very active in your behalf during the months of January and February as well as at the Chicago Convention. The loyalty of these men and their admiration for you is almost beyond description. To me it is a thrill and a privilege to have an even insignificant part in the organization that works in your behalf.

You may have heard that I have become a candidate for the office of mayor of Minneapolis. I have the united support of the American Federation of Labor, the C.I.O., and the Railroad Brotherhoods. Of course, I also have the endorsement and assistance of our local Democratic-Farmer-Labor organization as well as a broader community support from church, business and professional groups. In the election in 1943 I lost out by slightly less than 5,000 votes. At that time I had little or no organized support. The situation seems much improved this time and from all indications, there is a strong possibility that we will be successful. I cannot help but feel that success in this venture will mean something to the progressive cause. If, perchance, I should be elected, I am putting on my schedule a trip to Washington and I am going to make it my business to ask for an appointment with you in order that we may have an opportunity to have a visit and talk over some of the political and economic problems that confront our municipalities. 
I have had several letters from our mutual friend, Governor Arnall of Georgia. 5 He surely has done a tremendous job in that state and every progressive leader in America ought to be proud of his accomplishments.

A young friend of mine by the name of Mr. Lamoine M. Dowling was in to see me the other day and asked me to write to you in his behalf. He has been a loyal Democrat for the past fifteen years, having been a candidate for Congress in 1942 as well as one of the leaders in our recent state Democratic-Farmer-Labor Convention. Presently, he is the State Director of the Agricultural Census. Mr. Dowling tells me that there may be an opening here in Minnesota with the Bureau of Domestic and Foreign Commerce. I know that this Bureau is under your jurisdiction so I am referring his name to you for consideration. Mr. Dowling is an educated and trained person. He is well respected in this community and is $100 \%$ loyal to the Administration. I do not recall the name of the person who is in charge of the Bureau of Domestic and Foreign Commerce at present. However, he is a hold-over from the days of Jesse Jones. I do not know that you contemplate making any change in the local office of the Bureau but if you do and if you feel inclined to investigate the possibilities of the appointment of some local person here in Minneapolis or St. Paul, I would greatly appreciate having you give some consideration to Mr. Lamoine $\mathrm{M}$. Dowling. I am sure he will be writing to you in the near future and will present his record of experience and background. Any information you can give me in regard to this matter will be kept in the strictest confidence.

Again I want to express my sincere congratulations and to wish you the greatest of success. I only hope you are planning on coming out here to Minnesota sometime this summer. If it should happen that I become the mayor, you can rest assured that the welcome you will receive will be a most cordial and gracious one.

Respectfully yours

HHH: rt

Hubert H. Humphrey

\section{[The handwritten postscript:]}

I've just heard of the death of our great President. May God bless this nation and world.

I scarcely know what to say. It is as if one of my own family had passed away.

5 Ellis G. Arnall, Governor of Georgia from 1943 to 1947. 
If ever we needed men of courage-stout hearted men, it is now. I simply can't conceal my emotions. How I wish you were at the helm. I know Mr. Truman will rise to the heights of statesmanship so all important in this hour. But, we need you as you have never been needed before. ${ }^{6}$

At the time he received the above letter, Secretary Wallace was immersed in the study and correspondence involved in his still-new position. Nonetheless, he found time to reply to Humphrey on April 21,1945 , saying, in part,

With you, I share the faith that President Truman will rise to the heights of statesmanship which the present hour requires. He has gotten off to an unusually fine start. ${ }^{7}$

It is characteristic of Secretary Wallace's correspondence during this period that he emphasizes his support for President Truman. Thus, in addition to the content and timing of the Humphrey letter and postscript, this exchange of letters has additional value for scholars. Wallace's reply provides literal evidence of his loyalty to the early Truman administration. The possibilities of correct insight into this and other aspects of Henry Wallace's career will be immeasurably increased when the indexing of the Henry A. Wallace Manuscript Collection is completed and the papers are opened for scholarly research.

6 The original letter is in the Henry A. Wallace Manuscript Collection, Special Collections Department, The University of Iowa Libraries. It is here published with Mr. Humphrey's permission.

7 Quoted from a letter in the Wallace Collection and published with permission of the Wallace family. 


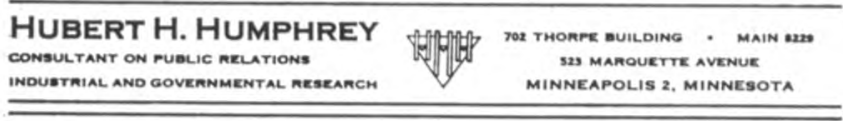

April 1\%, 1945

\begin{abstract}
Mr. Henry A. Wallace
Secretary of Commerce

Commerce Bullding

Washington, D. C.

Dear Mr. Wallace:

I have been intending to write to you for several weeks. First of all, I want to extend ry congratulations upon your appointment to the position of secretary of comerce. I need not tell you how happy and pleased all of us are out here in Minnesota because of your appointment to this important post in our government. Already favorable reports are coming to the attention of the public as to your activties in this office. The American people are going to heve their opsortunity to truly ovaluate and understand your practical approsch to the problems which confront our economy now and in the post war period. It makes all of us feel much more secure and much more hopeful as to the future when we know that vou are in a position where you can establish policy and influence the peneral trend of the post war planning and readjustment. I need not tell you that your beinp secretary of Comerce and coming directly in contact with the nations zruat industrial and business leaders will be of invalusble assistance to you in the deterininy of your politioal future. I want to keep reninding you that linnesota is expectinp. you to be our presidential candidate in 1948. As I pave said to you on previois ooosions, I will do everything within my power tonthbilize the progressive foroes in this great midwest area behind you and your progran.
\end{abstract}

Again I want to express my sincere congratulations and to wish you the preatest of success. I only hope you are planning on cominf out here to Minnesota sometime this sumer. If it should happen that I become the nayor, you can rest assured that the welcome you will receive will be a most cordial and gracious one.

HHH : rt

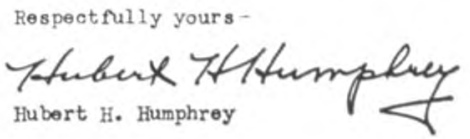

Opening and closing paragraphs of Hubert H. Humphrey's letter to Henry A. Wallace dated April 12, 1945. Item $42001 \mathrm{M}$ in the Henry A. Wallace Manuscript Collection. 


\section{diu just heard of the death of vis guax would. \\ d scarcely know euhat to bay. It is as if vne of my acve farmily had paseed away.}

Afuer rue needed men 7 caurag-<smiles>[CH]1CC1</smilesstaix hearted men, itis now. I simply cant conceal my emotions. How wish yow unbe at the helm. I bnow Mrifruman evill rise to the leight of Statesmanahip so all important in this haw. But, We sued yow as you ham nemer bue needed before.

Hubert Humphrey's handwritten postscript to his letter to Wallace, added minutes after he had learned of the death of President Franklin D. Roosevelt. 